\title{
Magnitude, frequency, trends of heat and cold waves in recent decades and impact assessment in wheat: the case of north Bihar, India
}

\author{
S. SHERAZ MAHDI ${ }^{1}$, B. S. DHEKALE ${ }^{2}$, SUBORNA ROY CHOUDHURY ${ }^{1}$, \\ MIZANUL HAQUE ${ }^{1}$ and SANJEEV KUMAR GUPTA ${ }^{1}$
}

\author{
${ }^{1}$ Department of Agronomy, Bihar Agricultural University, Sabour-813 210, Bhagalpur, Bihar, India; \\ ${ }^{2}$ Division of Agriculture Statistics, Bidhan Chandra Krishi Vishwavidyalaya, Mohanpur-741 252, West Bengal \\ Corresponding author: syedapbau@gmail.com
}

\begin{abstract}
The climatological distribution of heat and cold waves of two important agro-climatic zones zone-I (North Alluvial Plain), zone-II (North East Alluvial Plain) of the middle Indo-Gangetic Basin of Bihar state of India was analyzed. We used series of daily maximum and minimum temperature data from 1969-2015 of five stations. Results reveal that zone-I and zone-II experienced 248/184 and 275/199 average number of heat and cold events, respectively. The trend analysis exhibited almost similar results for both the zones. The zone-l experienced on an average 4.22 and 7.22 heat and cold wave days per season (hot $\&$ cold weather period), respectively. There was a non-significant increasing trend @ +0.04/ year for heat waves and significant decreasing trend for cold waves (-0.13/year). Zone-II on an average experienced 3 and $12 \mathrm{HW}$ and $\mathrm{CW}$ events per season (hot and cold weather period), respectively. In this zone, heat waves were found to be increasing @ +0.11/year, whereas, significant decreasing trend was found for cold waves $(+0.32 /$ year). Study also revealed that, heat waves were more frequent and longer in June and May in zone-I and zone-II, respectively. Whereas, cold waves were more frequent and longer in January for both the zones. These extreme events have profound impact on wheat crop if coincides with its critical stages. However, shifting planting dates and adoption of heat tolerant varieties may help in minimizing the negative impact of these extreme events.
\end{abstract}

Keywords: Extreme temperature, distribution, occurrence, duration, trend, climatology

The amount of damage wrought by weather-related natural disasters has skyrocketed in recent decades. Episodes of extreme heat and cold can have serious societal, agricultural, economic, and ecological impacts across the globe, with heat being the leading weather-related killers (National Weather Service, 2014). According to the recent IPCC report, (IPCC, 2014), warm days/nights, their frequency and duration has increased since 1950s and it is projected that there will be more frequent hot and fewer cold temperature extremes over most of land areas of Asia. The findings of Orlowsky and Seneviratne (2011), Clark et al., (2011) and Rajedran and Kitoh, (2008) have also reported the increases in the number of extremely hot days over East Asia and South Asia. Whereas, occurrence of cold nights/ days are observed to be decreasing at the rate 2.82/2.93 days per decade with significance at $99.9 \%$ confidence level (Kumar et al.,2013). Fine resolution projections (at $0.44^{\circ}$ ) over south Asia, obtained using PRECIS (Providing Regional Climates for Impacts Studies), indicate an increase in temperature extremes toward the end of the twenty-first century for $\mathrm{A} 2$ and $\mathrm{B} 2$ scenarios using CMIP 3 projection (Revadekar et al., 2012). However, different regions are expected to experience differential change in the amount, magnitude and frequency of such extreme weather abnormalities and their impacts (IPCC, 2007, 2012). Temperature extremes have profound impact on human society and natural environment (Esterling et al., 2000). Computer simulation and experimental studies have amply proved that temperature variability and its extremes increase the risks to crop yields (Porter and Semenov, 2005; Chawade et al., 2013).

In India, heat wave and cold wave conditions are generally experienced during the period from March to July (hot weather period) and from December to February (cold weather period) respectively. In tune with the global warming trend, a warming trend over India in the range of 0.8 to $1{ }^{\circ} \mathrm{C}$ per century has been observed (Kothawale et al., 2010, 2012), with an increasing number of hot days, defined as 
days with daily maximum temperature exceeding the 90 th percentile of the time series from 1969 to 2005 (Dash and Mamgain, 2011). Northern India shows high occurrence of heat waves, averaging between five and six per year (De et al., 2005). Singh and Patwardhan (2012), while studying the spatio-temporal distribution of extreme weather events in Indian for the period 1967-2006 (missing year 1977) found significantly increasing trends in heat and cold waves. Whereas, Dash and Mamgain, (2011), has reported significant decreasing trends in the frequency and spells of cold nights for the period 1969-2005 in the India as a whole and in all the regions in the north except the western Himalaya. However, a significant increasing trend in the number of warm days in summer has been noticed only in the interior peninsula. In the entire country and on the east coast and west coast, the maximum number of warm days in summer has been noticed only during the decade (1996-2005). Pai et al., (2013), linking heat and severe heat waves with ESNO phenomena has inferred significant long-term increasing trends in heat wave days over India during the analysis period (1961-2010). However, few stations have shown significant decreasing trend in heat waves ( 2 stations from north India $\& 3$ stations from east coast) and severe heat waves ( 2 stations from east coast). In general, the frequency, persistency and area coverage of the heat wave and severe heat days were found to be more than average during years succeeding El Nino $($ El Nino +1$)$ years.

Bihar state in India has been traditionally vulnerable to hydro-meteorological natural disasters, with north Bihar being highly flood-prone and south Bihar being highly drought-prone. The northern and southern Bihar were assessed to be most vulnerable regions to climate change in the Indo-Gangetic Plains (IGP) owing to high exposure, high sensitivity and low adaptive capacity of people(Sehgal et al., 2013). Weather related extremes (heat and cold waves, floods, droughts, cyclones) have been a recurrent phenomenon, which affects more than $45 \%$ of the geographical area of the state (Economic Survey, 2014) and leading to enhanced stresses through atmospheric factors (Bal and Minhas, 2017). Frequent disasters are often attributed to the state's ever-increasing population (103.8 million), its growth rate (25.42\%/decade) and density (1102 people per Sq.km) which has made the region second most populous state in India (Economic Survey, 2014). Highest poverty head count ratio (HCR) at 33.7 per cent andnearly 92.5 per cent of 16.4 million land holdings of fragmented, small and marginal size further aggravates the problem of environmental degradation (Anonymous, 2012). In this study, the main aim is to use local weather (temperature) information at district level over 47 years (1969-2015) period to examine the climatology and trends in the occurrence, frequency and duration of heat and cold waves to generate the information at local level to address the challenge of climate change and its extremes. In addition, impact assessment of extreme temperature (heat waves) on wheat phenology and yield was also studied using modelling approach to suggest the regional adaptation options to overcome potential challenges of climate change extremes.

\section{MATERIALS AND METHODS}

Bihar lies in the eastern region of India extending from 25.09 $\mathrm{N}$ latitude and 85.31 E longitude, covering a total area of $94,163 \mathrm{sq} . \mathrm{km}$ lying at an average altitude of $52.73 \mathrm{~m}$ above sea level. Based on soil characterization, rainfall, temperature and terrain, four main agro-climatic zones in Bihar have been identified, viz. Zone-I (North Alluvial Plain), Zone-II (North East Alluvial Plain), Zone-IIIA (South East Alluvial Plain) and Zone-IIIB, (South West Alluvial Plain), each with its own unique prospects. In this study, we selected zone-I and II, located in the north of river Ganga and comprises of 19 districts withtotal geographical area of 53.3 thousand square $\mathrm{km}$. Rice, wheat, maize and pulses as principal agricultural crops grown in these zones. The data used in this study are the daily maximum and minimum temperatures of recent 47 years (1969-2015) of five meteorological stations lying in agro-climatic zone I\& II of north Bihar obtained from Meteorological Centre, Patna and Indian Meteorological Department, Pune, where all climatological data of India are processed, quality checked, and archived. At first, daily values of maximum and minimum temperature from all the meteorological station data (available for particular zone) were averaged to represent a particular agro-climatic zone and in order to derive heat and cold wave information, daily climate normals of the maximum and minimum temperatures for the hot weather (March- July) and cold weather (December to February) period were computed using the equation:

$$
\overline{\mathrm{x}}_{\mathrm{i}}=\frac{\sum_{\mathrm{j}=1}^{\mathrm{n}} \mathrm{x}_{\mathrm{i}}}{\mathrm{n}}
$$

Where, $\mathrm{j}=1,2 \ldots .45 ; \mathrm{i}=1,2 \ldots 365$ and $\mathrm{n}=47$

Using these daily climate normals of maximum and minimum temperature data, daily anomalies were computed and using the criteria given in the Table 1, days that satisfied the heat wave (HW)/severe heat wave (SHW) and cold wave 
Table 1: Criteria for HW/SHW and CW/SCW for plain region used in this study (IMD, 2002)

Heat event When the climate normal maximum temperature of a station is $<40^{\circ} \mathrm{C}$ :

(HW): Departure from climate normal is $+5^{\circ} \mathrm{C}$ to $6^{\circ} \mathrm{C}$

(SHW): Departure from climate normal is $+7^{\circ} \mathrm{C}$ or more

When the climate normal maximum temperature of a station is $\mathrm{e} " 40^{\circ} \mathrm{C}$ :

(HW): Departure from climate normal is $+4^{\circ} \mathrm{C}$ to $5^{\circ} \mathrm{C}$

(SHW): Departure from normal is $+6^{\circ} \mathrm{C}$ or more

Cold event When climate normal minimum temperature is equal to $10^{\circ} \mathrm{C}$ or more.

$\mathrm{CW}$ : Departure from climate normal is $-5^{\circ} \mathrm{C}$ to $-6^{\circ} \mathrm{C}$.

SCW: Departure from climate normal is $-7^{\circ} \mathrm{C}$ or less

When climate normal minimum temperature is less than $10^{\circ} \mathrm{C}$.

$\mathrm{CW}$ : Departure from climate normal is $-4^{\circ} \mathrm{C}$ to $-5^{\circ} \mathrm{C}$.

SCW: Departure from climate normal is $-6^{\circ} \mathrm{C}$ or less

$(\mathrm{CW}) /$ severe cold wave (SCW) conditions were identified.

This formed the basic information for examining various climatological features and trends in the heat and cold event conditions over these two agro-climatic zones in this study. Quinquennial variation in all heat and cold events was examined. For this total number of $\mathrm{HW} / \mathrm{SHW}$ and $\mathrm{CW} / \mathrm{SCW}$ for each season was computed. The trend and the year to year changes in the number of heat and cold events in each year during the entire data period (1969-2015) were also examined. For computing trends, simple linear regression method was used.

\section{Heat wave/severe heat wave and cold wave/severe cold wave definition and features}

There is no universal definition of a heat or cold waveas both temperature extremes vary from region to region depending up on the climate normals (average of 30 years) of maximum and minimum temperature. Here, we use the definition of heat wave/severe heat wave and cold wave/ severe cold wave as per the criteria provided by the IMD (2002), based on maximum and minimum daily temperature thresholds.

\section{Heat wave and severe heat wave}

In case a climate normal maximum temperature of a station is less than or equal to $40^{\circ} \mathrm{C}$, that day is defined as heat wave day when (1) the day's maximum temperature is at least $5^{\circ} \mathrm{C}$ to $6^{\circ} \mathrm{C}$ greater than the climate normal temperature and severe heat day when (2) the day's maximum temperature is at least $7^{\circ} \mathrm{C}$ greater than the climate normal temperature.

If the climate normal maximum temperature of a station exceeds $40^{\circ} \mathrm{C}$, that day is defined as heat wave day when (1) the day's maximum temperature is at least $4^{\circ} \mathrm{C}$ to $5^{\circ} \mathrm{C}$ greater than the climate normal temperature and severe heat day when (2) the day's maximum temperature is at least $6^{\circ} \mathrm{C}$ greater than the climate normal temperature. If the maximum temperature of a day exceeds $45^{\circ} \mathrm{C}$, irrespective of the climate normal maximum temperature of a region, that day is defined as a severe heat wave day.

\section{Cold wave and severe cold wave}

For declaring the cold wave situation, wind chill effective minimum temperature (WCTn) factor is considered which is defined as the effective minimum temperature due to wind flow. For example, when the minimum temperature is $15^{\circ} \mathrm{C}$ and the wind speed is $10 \mathrm{mph}, \mathrm{WCTn}$ will be $10.5^{\circ} \mathrm{C}$.

In case when climate normal minimum temperature of a station is equal to $10^{\circ} \mathrm{C}$ or more, that day is defined as cold wave day when (1) the departure of minimum temperature from climate normal is $-5^{\circ} \mathrm{C}$ to $-6^{\circ} \mathrm{C}$ and severe cold day when (2) when departure of minimum temperature from climate normal is $-7^{\circ} \mathrm{C}$ or less.

If climate normal minimum temperature of a station is less than $10^{\circ} \mathrm{C}$, that day is defined as cold wave day when (1) the departure of minimum temperature from climate normal is $-4^{\circ} \mathrm{C}$ to $-5^{\circ} \mathrm{C}$ and severe cold day when (2) the departure of minimum temperature from climate normal is $6^{\circ} \mathrm{C}$ or less.

\section{Impact Assessment of extreme temperature (heat waves) on wheat crop}

Calibrated and validated CERES-Wheat model (DSSATv.4.6) for popular wheat variety viz. HD2733 of Biharwas used for impact assessment study (Mahdi and 
Table 2 : Impact of heat waves stress at different crop growth stages on phonology and yield of wheat var. HD2733 using wheatCERES DSSAT V4.6 model at Sabour, Bihar

\begin{tabular}{lrrrrrrrr}
\hline Treatment & \multicolumn{3}{c}{ Booting-Anthesis } & & \multicolumn{3}{c}{ Anthesis-Milk } \\
\cline { 2 - 3 } \cline { 7 - 8 } & $\begin{array}{r}\text { Days to } \\
\text { anthesis }\end{array}$ & $\begin{array}{r}\text { Days to } \\
\text { physiological } \\
\text { maturity }\end{array}$ & $\begin{array}{r}\text { Yield } \\
\left(\mathrm{kg} \mathrm{ha}^{-1}\right)\end{array}$ & & $\begin{array}{r}\text { Days to } \\
\text { anthesis }\end{array}$ & $\begin{array}{r}\text { Days to } \\
\text { physiological } \\
\text { maturity }\end{array}$ & $\begin{array}{r}\text { Yield } \\
\left(\mathrm{kg} \mathrm{ha}^{-1}\right)\end{array}$ \\
\hline Normal (No heat stress) & 92.0 & 124.0 & 4926 & & 92.0 & 124.0 & 4926 \\
Temperature increased by $+5^{\circ} \mathrm{C}$ & 89.0 & 119.0 & 3840 & & 91.0 & 117.0 & 3690 \\
Deviation from normal (Days/Percent) & -3.0 & -5.0 & -22.04 & & -1.0 & -7.0 & -25.09 \\
Temperature increased by $+7^{\circ} \mathrm{C}$ & 87.0 & 116.0 & 3660 & & 90.0 & 115.0 & 3495 \\
Deviation from normal (Days/Percent) & -5.00 & -8.0 & -25.70 & & -2.33 & -9.00 & -29.05 \\
\hline
\end{tabular}
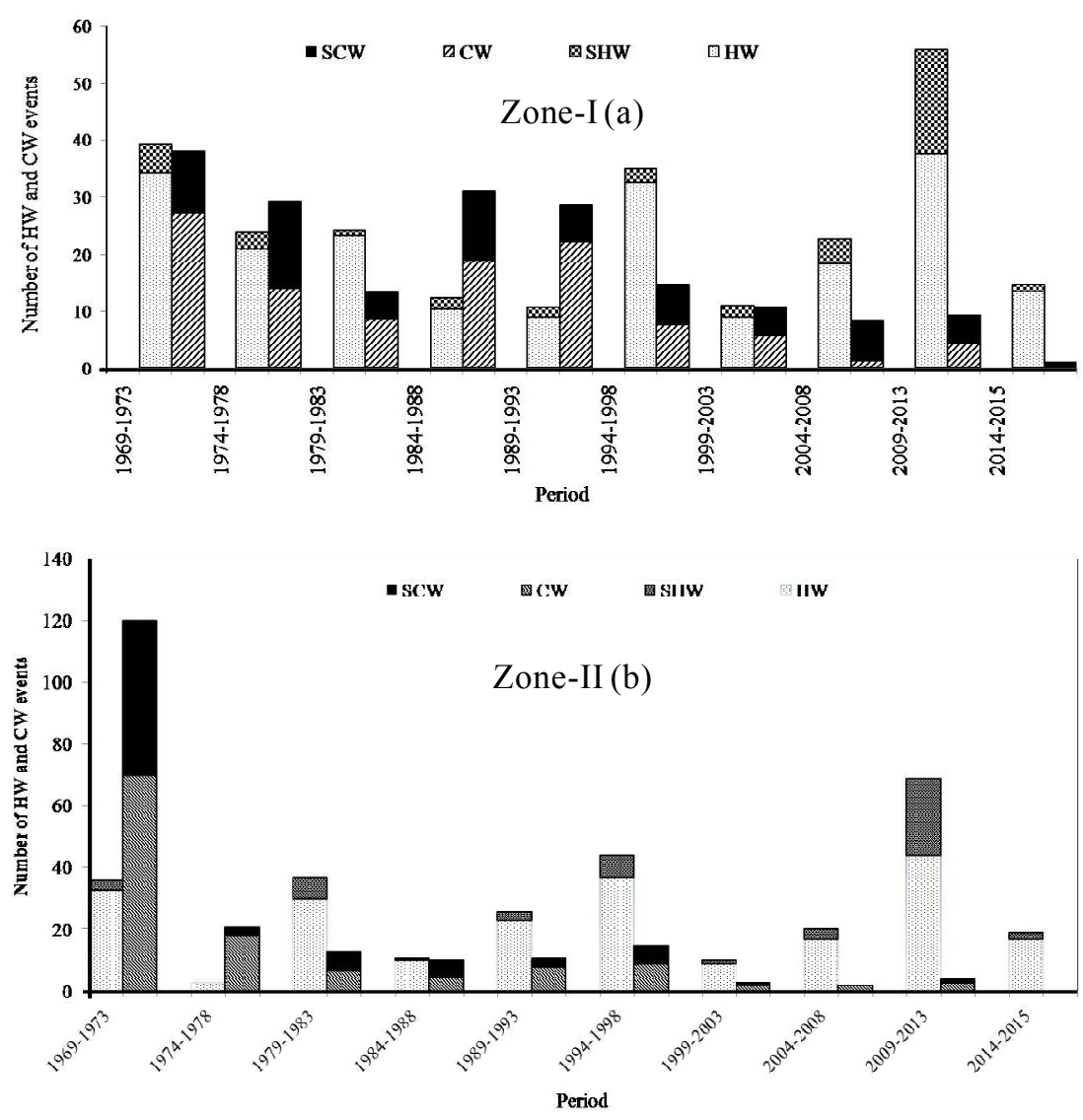

Fig. 1 : Quinquennial variation in heat and cold events over agro-climatic zone I (a) \& II (b) of Bihar.

Haque, 2018). The widely accepted approach to analyze possible effects of different climatic parameters on crop growth and yield is by specifying the incremental changes to climatic parameters and applying these changes uniformly to baseline/ normal climate (Hundal and Kaur, 2007). Sensitivity analysis was performed to know the role short exposure (4-6 days) of extreme maximum temperature (heat stress) at certain critical crop growth stages (booting to anthesis and anthesis to milking). This was done by increasing the maximum temperatures (mean) only from $5^{\circ} \mathrm{C}$ to $7^{\circ} \mathrm{C}$ from normal at above stages of crop growth without changing the minimum temperature. The carbon dioxide $\left(\mathrm{CO}_{2}\right)$ level was kept constant at $390 \mathrm{ppm}$ in each run and simulation.

\section{RESULTS AND DISCUSSION}

\section{Heat and cold events (Quinquennial variation)}

The quinquennial variation of total HW/SHW and 

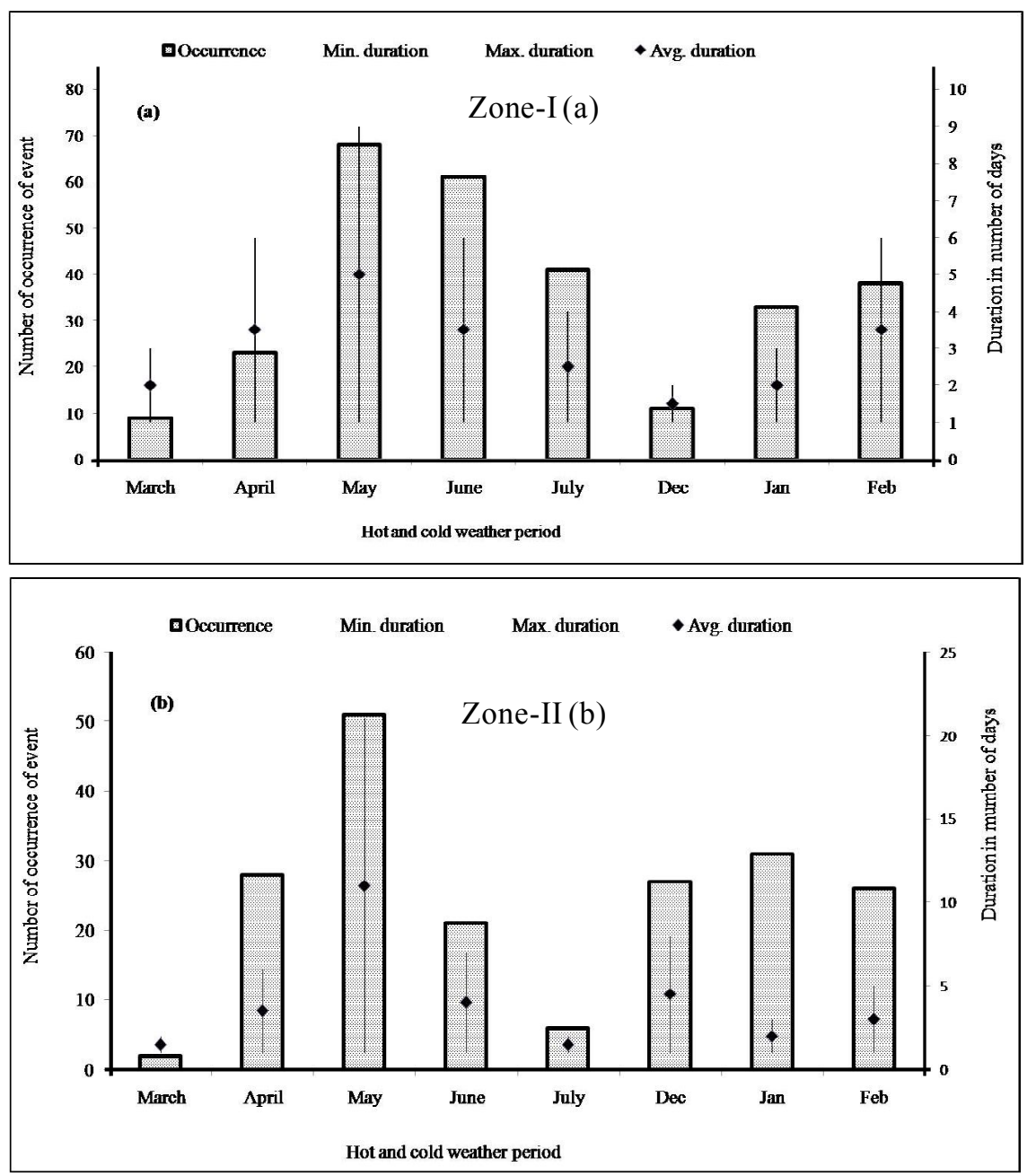

Fig. 2 : Frequency distribution of heat and cold events over Agro-climatic zone I (a) \&II (b) of Bihar

$\mathrm{CW} / \mathrm{SCW}$ days for the nine quinquennials during the period 1969-2015 in agro-climatic zone-I \& II of Bihar is shown in the Fig.1.

From the perusal of the data, Zone-I in first three quinquennials (1969-73, 1974-78 and 1979-83) has experienced 87 number of heat wave days, after which the number of heat events has decreased to 58 in the middle three quinquennials (1984-88, 1989-93 and 1994-1998) and then increased to 103 days and in last three quinquennials (1999-03, 2004-08 \& 2009-13 \& 14-15) respectively. With respect to cold events, the zone has experienced 81 number of cold events during the first three quinquennials (196973, 1974-78 and 1979-83), after which the number of cold events has decreased to 74 and 29 days in the middle three (1984-88, 1989-93 and 1994-1998) and in last three quinquennial (1999-03, 2004-08 \& 2009-13 \& 14-15), respectively.

Zone-II, in the first three quinquennials (1969-73,
1974-78 and 1979-83) has experienced 76 number of heat events after which the number of heat episodes has increased to 81 and 118 days in the middle (1984-88, 1989-93 and 1994-1998) and in the last three (1999-03, 2004-2008, 2009-13 and 14-15) quinquennials. With respect to cold events, the zone in first three quinquennials (1969-73, 1974-78 and 1979-83) has experienced 154 number of cold days, which has decreased to 36 and 9 days in the middle (1984-88, 1989-93 and 1994-1998) and in the last three quinquennial (1999-03, 2004-2008 \& 2009-13) with zero number in 2014-15.

\section{Frequency of heat and cold events}

Data on the month wise distribution of HW/SHW and $\mathrm{CW} / \mathrm{SCW}$ events of agro-climatic zone-I and II has been shown in Fig. 2. The results revealed that, in Zone-I, month 'May' is experiencing highest number of HW (104) and SHW (32) spells, followed by month 'June' with $55 \mathrm{HW}$ and 7 SHW spells. Whereas, the month 'March', 'April', and 



Fig. 3 : Duration of heat and cold events over agro-climatic zone I (a) \& II (b) of Bihar

'July' have experienced lowest number of 08,21 and $21 \mathrm{HW}$ and 0,0 and 1 SHW spells respectively. With respect to the CW events, 'January' and 'February' months are experiencing maximum number of 33 and $36 \mathrm{CW}$ and 31 and $25 \mathrm{SCW}$ spells respectively, whereas, December month has recorded highest (41 CW) and lowest (17 SCW) number of spells respectively.

In Zone-II, again month 'May' is experiencing highest number of HW (130) and SHW (37) spells, followed by month 'April' with $48 \mathrm{HW}$ and 03 SHW spells. Whereas the month March and June, July have experienced lowest number of 03, 35 and $07 \mathrm{HW}$ and 0, 09 and 0 SHW spells respectively. With respect to the $\mathrm{CW}$ events, month February is experiencing maximum number of $41 \mathrm{CW}$ and $42 \mathrm{SCW}$ spells respectively, whereas, December and January month has recorded lowest number of $46,37 \mathrm{CW}$ and 10 and $23 \mathrm{SCW}$ spells respectively. It was inferred that probability of maximum number of occurrence of $\mathrm{HWs}$ /SHWs remains in the month of May for both zones than other months of hot weather period. Whereas, for $\mathrm{CWs} / \mathrm{SCW}$ s the probability of maximum number of events remains in the month February in both zones.

\section{Duration andIntensification of $\mathrm{HW}$ and $\mathrm{CW}$ events}

Data on duration and intensification of $\mathrm{HW}$ and $\mathrm{CW}$ events for agro-climatic zone I and II is presented in Fig. 3 and 4 respectively. In zone-I, $\mathrm{HW}$ and $\mathrm{CW}$ events have registered an average duration of 3.3 and 2.33 days, whereas, for the characterization of intensity of $\mathrm{HW}$ and $\mathrm{CW}$ events, the departure from climate normals of maximum and minimum temperature have been noticed within the range of +4.90 to $+9.97^{\circ} \mathrm{C}$ and -4.00 to $-5.93^{\circ} \mathrm{C}$ respectively. HW events of month June and July were hotter registering average departure of $+7.07^{\circ} \mathrm{C},+7.44^{\circ} \mathrm{C}$ from climate normals of maximum temperature. However, they last longer in the month of May with an average duration of 5.0 compared to other months viz. March, April, June and July which recorded 

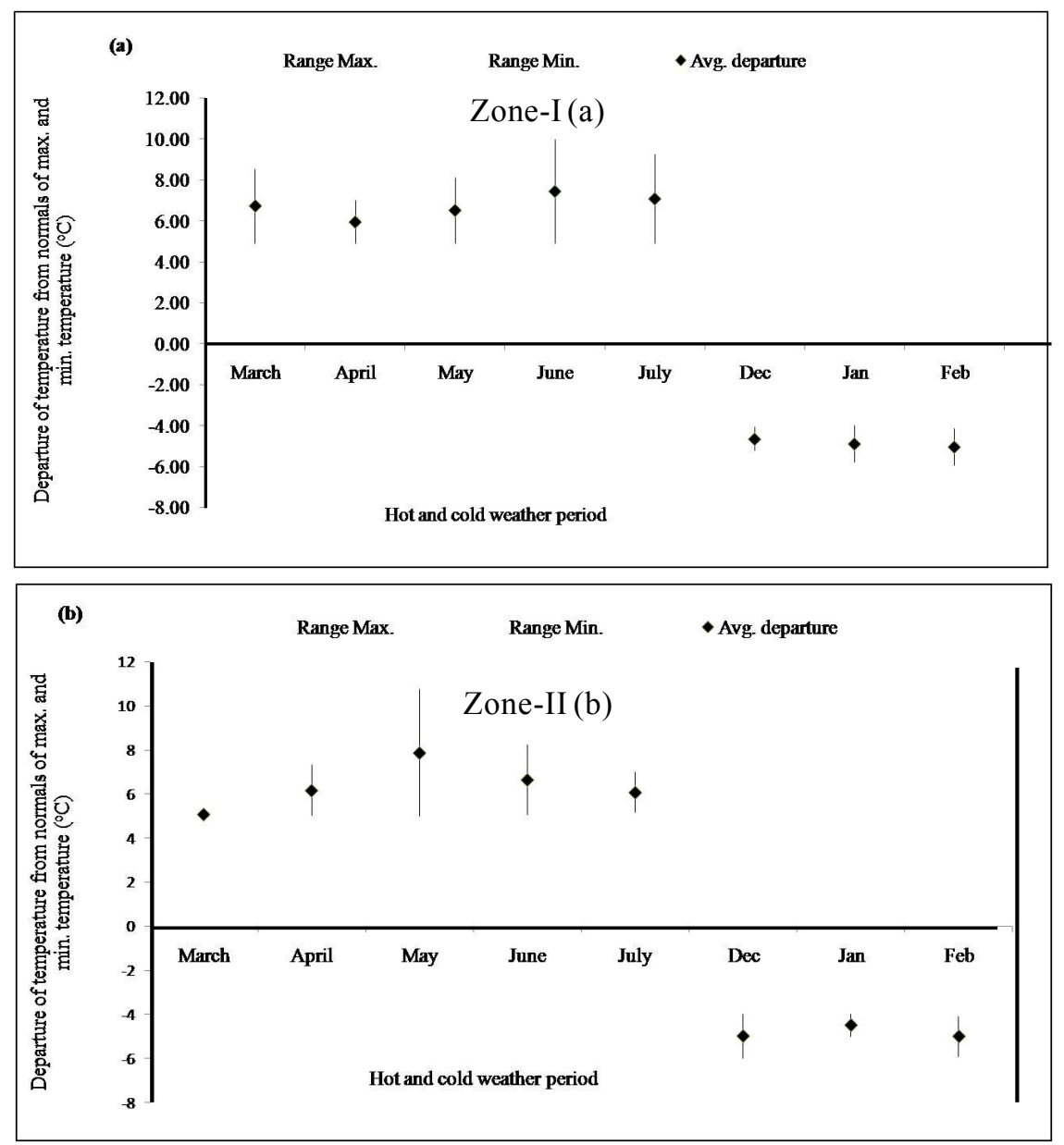

Fig. 4 : Intensity of heat and cold events over agro-climatic zone I (a) \& II (b) of Bihar

average duration of duration 2.0, 3.5, 3.5 and 2.5 days respectively. Longest heat wave of 10 consecutive days and magnitude (average departure $+6.75^{\circ} \mathrm{C}$ from climate normal maximum temperature) was observed in the May month. We inferred from the study that heat waves of month May although not hotter but are more frequent and longer than the other months of hot weather period under study.

With regard to $\mathrm{CW}$ events, the January and February months were identified more longer recorded an average duration of 2.5 and 3.5 days and colder registering average departure of $-4.89^{\circ} \mathrm{C}$ and $-5.04^{\circ} \mathrm{C}$ from climate normals of minimum temperature respectively, compared to month December which recorded an average duration of 1.5 consecutive days and departure of $-4.65^{\circ} \mathrm{C}$ from climate normals of minimum temperature. The longest cold wave of 7.0 consecutive days with magnitude (average departure $5.18^{\circ} \mathrm{C}$ from climate normal of minimum temperature was observed in the month of February.

In Zone-II, HW and $\mathrm{CW}$ events have registered the duration range of 1 to 21 and 1 to 8 consecutive days respectively, whereas, for the characterization of intensity of the HW and CW events, the departure from climate normals of maximum and minimum temperature have been noticed within the range of +5.00 to $+10.74^{\circ} \mathrm{C}$ and -4.00 to $-5.99^{\circ} \mathrm{C}$ respectively. HW events of the month May were identified longer recorded average duration of 11 consecutive days and hotter registering average departure of $+7.87^{\circ} \mathrm{C}$ from climate normals of maximum temperature, followed by month June, April, July and March which recorded average duration of 4.0, 3.5, 1.5 and 1.5 consecutive days and registering average departure of $+6.65^{\circ} \mathrm{C},+6.16^{\circ} \mathrm{C},+6.07^{\circ} \mathrm{C}$ and $5.08^{\circ} \mathrm{C}$ from climate normals of maximum temperature.

With respect to the $\mathrm{CW}$ events, the month January recorded maximum occurrence of cold spells. However, month December exhibited longer duration of cold spells averaging of 4.5 number consecutive days with average departure of $-5.0^{\circ} \mathrm{C}$ from climate normal of minimum temperature, followed by month February and January which recorded average duration of 3.0 and 2.0 consecutive days 

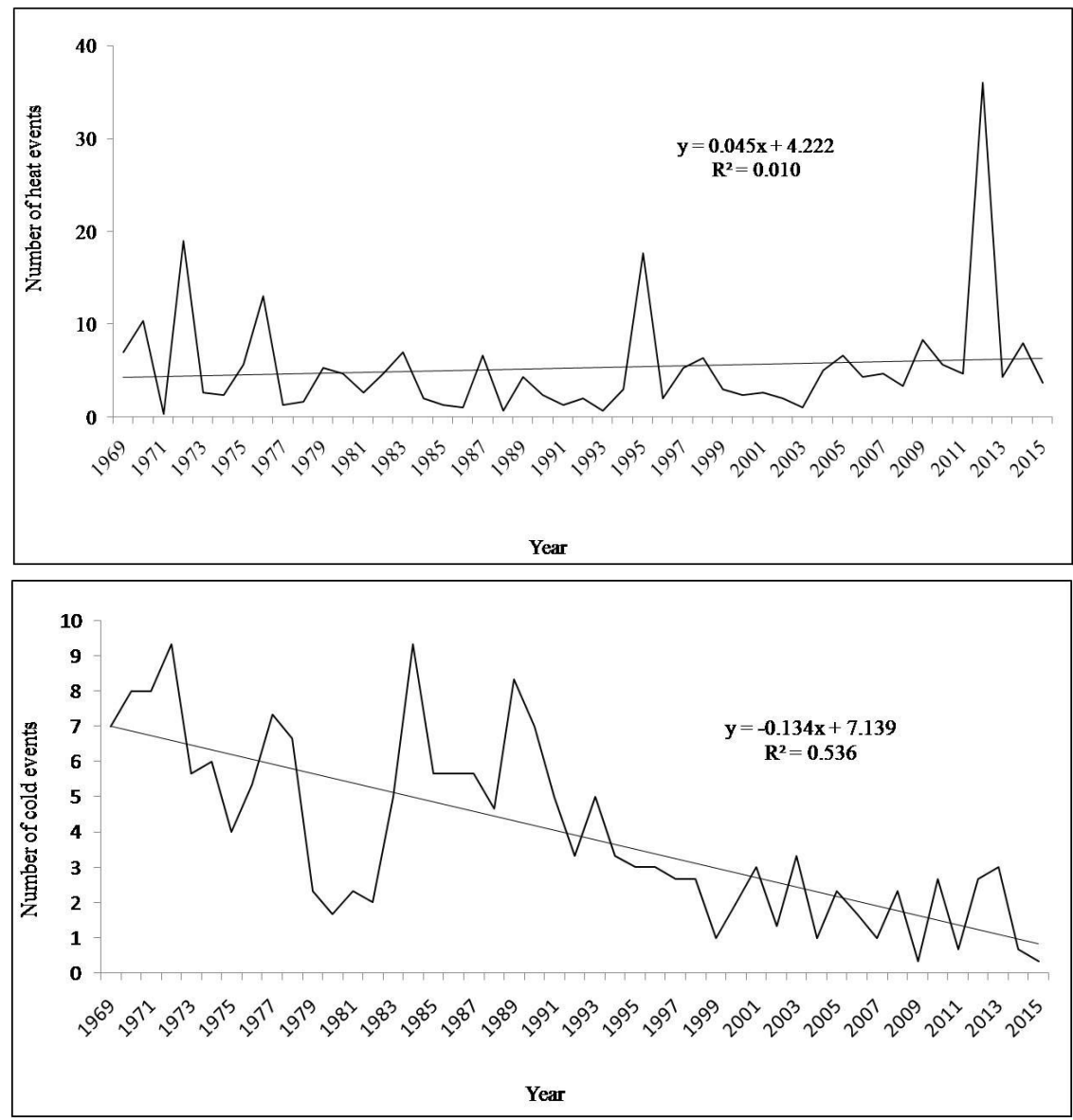

Fig. 5 : Seasonal trend analysis of heat and cold events over agro-climatic zone I of Bihar.

(Note: *indicates significance at $5 \%$ level)

and registering average of departure of $-5.0^{\circ} \mathrm{C}$ and $-4.5^{\circ} \mathrm{C}$ respectively.

\section{Trend analysis of $\mathrm{HW}$ and $\mathrm{CW}$ events}

Seasonal trend analysis of total $\mathrm{HW}$ and $\mathrm{CW}$ records over zone-I is shown in Fig. 5. The trend analysis exhibited almost similar results in two zones. Agro-climatic Zone-I on an average is experiencing 4.22 and 7.22 heat and cold wave days per season (hot \& cold weather period) respectively, but, heat waves although not significant, have been found increasing at the rate 0.04 year. Whereas, cold waves have been decreasing significantly at the rate -0.13 /year. Whereas, agro-climatic zone-II on an average is experiencing 3 and 12 HW and CW events per season (hot and cold weather period), but, heat waves have been found increasing at the rate 0.11 /year, whereas, significant decreasing rate of 0.32 / year was observed in cold waves (Fig. 6).

\section{Impact of extreme temperature (heat wave) on wheat crops}

Variability in rainfall and temperatures and sudden onset of extremes (dry spells, droughts, floods, heat waves and hailstorm) adversely affects crop yields leading to low level of productivity (Bal and Minhas, 2017). The days to attain different growth and development stages of wheat cultivar (HD2733) were reduced in extreme temperature (heat wave) induced treatments compared to control (no heat stress) (Table 1). Under ambient condition, the days taken to anthesis and physiological maturity were 92 and 124 days, which were reduced significantly to 89/87 and $118.82 / 116$ days for treatments experienced heat stress of $+5^{\circ} \mathrm{C}$ and $+7^{\circ} \mathrm{C}$ temperature, respectively over normal at booting to anthesis. However, the magnitude of stress was more pounced on physiological maturity in treatments receiving heat stress at anthesis to milk stage. The days taken to physiological maturity were observed to be 117 days at $+5^{\circ} \mathrm{C}$ and 115 days at $+7^{\circ} \mathrm{C}$ over normal. Owing to higher temperature stress, the final yield reduction was observed to be 25.09 and 29.05 per cent at temperature of $+5^{\circ} \mathrm{C}$ and $+7^{\circ} \mathrm{C}$ respectively, which can be attributed to increased rate of grain filling and reduced the grain filling duration (Jalota et al., 2013; Yin et al., 2009). 

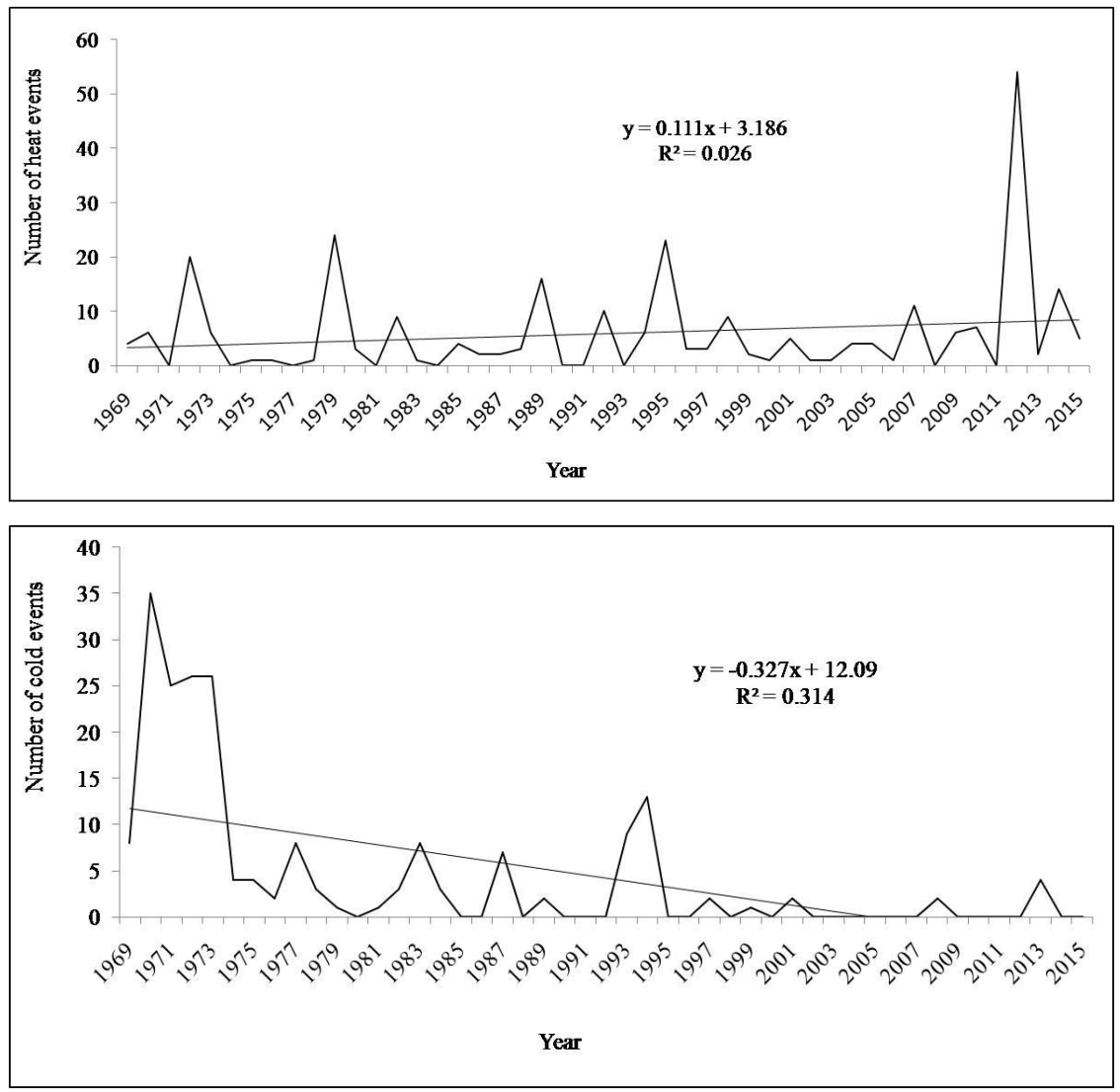

Fig. 6 : Seasonal trend analysis of heat and cold events over agro-climatic zone II of Bihar.

(Note: * indicates significance at $5 \%$ level)

\section{Strategies for adaptation}

Adaptation to climate extremes serves as a basis for reducing vulnerability to long term climate change and its associated risks. Some of the strategies developed to manage year-to-year climate variability can go a long way towards building resilience and managing the risks of climate. Few of the strategies are adjustment of planting dates (early or late sowing) to avoid heat stress during flowering and maturity of crop; Some of candidate genotypes like 'Sabour Shrestha', DWB107 and DWB14 in wheat (average yield potential of 4.0-4.3 tonnes per hectare) and 'Sabour Ardhjal', 'BRR0006' in rice crop (average yield potential of 5.0-5.3 tonnes per hectare) has been tested and were found best for resilience to heat and drought stress; Application of potassium nitrate $\left(\mathrm{KNO}_{3}\right)$ at the rate $0.5 \%$ at boot to anthesis stage of wheat crop (sown under late conditions: 15-30 December) has been found effective in mitigating higher temperature stress. Using long term local weather data for identifying consequences of climate change like extreme weather events and its effects of local environment needs immediate attention for effective agricultural planning and its management.

\section{CONCLUSION}

The trend analysis exhibited almost similar results in both zones. Agro-climatic Zone-I on an average is experiencing 4.22 and 7.22 heat and cold wave days per season (hot \& cold weather period) respectively, but, heat waves although not significant, have been found increasing at the rate $+0.04 /$ year. Whereas, cold waves have been decreasing significantly at the rate $-0.13 /$ year. Whereas, zone-II on an average is experiencing $3(\mathrm{HW})$ and $12(\mathrm{CW})$ events per season (hot and cold weather period), but heat waves have been found increasing at the rate +0.11 /year, whereas, significant decreasing rate of +0.32 year was observed in cold waves. Thus, the result indicates increases in warm days during hot and cold weather period, which may pose additional threat to the yields under rice-wheat system in both regions. Study further concludes that heat waves of month June in zone-I and of May in zone-II are more frequent, hotter and longer than other months of hot weather period under study, whereas, cold waves of month January are more frequent and longer in both zones. On exposing the wheat crop at critical growth stages to shorter period of 
extreme temperature from 5 to $7^{\circ} \mathrm{C}$ above normal (ambient), the results revealed significant reduction in days to anthesis, physiological maturity and $29 \%$ average decline in yield of wheat at Sabour. Some of the strategies like adoption of heat tolerant varieties, shifting of sowing dates etc. can be adopted to minimize the negative impact of these extreme events.

\section{ACKNOWLEDGEMENT}

The authors gratefully acknowledge financial support from Science and Engineering Research Board, Department of Science and Technology (SERB-DST), New Delhi, India.

\section{REFERENCES}

Anonymous (2012). Bihar Statistical Hand Book, Directorate of Economics and Statistics, Department of Planning and Development, Government of Bihar. p 338.

Bal, S.K. and Minhas, P.S. (2017). Atmospheric Stressors: Challenges and Coping Strategies. In: "Abiotic Stress Management for ResilientAgriculture". (Eds. P.S. Minhas et al.). pp. 9-50, Springer Nature Singapore Pte.Ltd.

Chawade, A., Lindlof, A., Olsson, B. and Olsson, O. (2013). Global expression profiling of low temperature induced genes in the chilling tolerant Japonica rice Jumli Marshi; Plos One, 8(12): 1-15.

Clark, R.T., Murphy, J.M. and Brown, S.J. (2011). Do global warming targets limitheat wave risk; Geophy. Res. Let., 37: (L17703).

Dash, S.K. and Mamgain,A. (2011). Changes in the frequency of different categories of temperature extremes in India. J. Appl. Meteorol. Climatol., 50:1842 1858.

De, U.S., Dube, R.K. and Prakasa Rao, G.S. (2005). Extreme weather events over India in the last 100 years. J. Ind. Geophy. Union, 9(3): 173-187.

Easterling, D.R., Meehl, G.A., Parmesan, C., Changnon, S.A., Karl, T.R. and Mearns, L.O. (2000). Climate extremes: observations, modeling, and impacts. Science, 289(5487): 2068-2074.

Economic Survey (2014). Finance Department, Government of Bihar, p 426. finance.bih.nic.in/Documents/Reports/ Economic-Survey-2015-EN.pdf

Hundal, S.S. and Kaur, P. (2007). Climatic variability and its impact on cereal productivity in Indian Punjab. Curr. Sci., 92: 506-512

IMD. (2002). Recommendation regarding the revised criteria for declaring heat wave/ cold wave, DDGM(WF). UOI. No. W-969/1304 to 1365 dated February 2002, India Meteorological Department, Pune, India.

IPCC (2007). Climate Change 2007: The Physical Science Basis, Contribution of Working Group I to the Fourth Assessment Report of the Intergovernmental Panel on Climate Change: Solomon SD, Qin M, Manning Z, Chen M, Marquis K B, Averyt M, Tignor and H L Miller eds. Cambridge UniversityPress, Cambridge United Kingdom and New York N Y USA.

IPCC. (2012). Managing the Risks of Extreme Events and Disasters to Advance Climate Change Adaptation, A Special Report of Working Groups I and II of the Intergovernmental Panel on Climate Change Field: C B V Barros T F, Stocker D, Qin D J, Dokken K L, Ebi M D, Mastrandrea K J, Mach G K, Plattner S K, Allen M, Tignor, and P M Midgley, eds: Cambridge University Press, Cambridge UK and New York N Y USA 582 pp.

Jalota, S.K., Kaur, H., Ray, S.S., Tripathy, R., Vashisht, B.B. and Bal, S.K. (2013). Past and General Circulation Modeldriven future trends of climate change in Central Indian Punjab: ensuing yield of rice-wheat cropping system. Current Sci., 104(1): 105-110

Kothawale, D. R., Kumar. K. K. and Srinivasan, G. (2012). Spatial asymmetry of temperature trends over India and possible role of aerosols. Theor. Appl .Climatol., 110:263-280. doi:10.1007/s00704-012- 0628-8

Kothawale, D.R., Revadekar, J.V. and Kumar, K.R. (2010). Recent trends in pre-monsoon daily temperature extremes over India. J. Earth Syst. Sci., 119:51-65

Kumar, P., Wiltshire, A., Mathison, C., Asharaf, S., Ahrens, B., Lucas Picher, P., Christensen, J. H., Gobiet, A., Saeed, F., Hagemann, S. and Jacob, D. (2013). Downscaled climate change projections with uncertainty assessment over India using a high resolution multi model approach. Sci. Total Environ., 468-469: S18-S30.

Mahdi, S.S. and Haque, M.(2018). Calibration and validation of CERES-Wheat(DSSAT v4.6) model for wheat under irrigated conditions: Model evaluation and application, Ind. J. Ecol., 45(3): 555-559

National Weather Service (2014). Heat:Amajor killer Available online at www.nws.noaa.gov/os/heat/index.shtml.

Orlowsky, B. and Seneviratne, S.I. (2011). Global changes in extreme events: Regional and seasonal dimension. Climatic Change, 110(3-4): 669-696. 
Pai, D.S., Nair. S.A. and Ramanathan, A.N. (2013). Long term climatology and trends of heat waves over India during the recent 50 years 1961-2010. Mausam, 64(4): 585604.

Porter, J.R. and Semenov, M.A. (2005). Crop response to climatic variation. Phil. Trans. R. Soc. B., 360: 20212035.1

Rajendran, K. and Kitoh, A.(2008). Indian summer monsoon in future climate projection by a super high-resolution global model. Curr. Sci., 95(11): 1560-9.

Revadekar, J.V., Kothawale, D.R., Patwardhan, S.K., Pant, G.B. and Kumar, K.R. (2012). About the observed and future changes in temperature extremes over India. Natural Hazards, 60(3): 1133-1155.
Sehgal, V.K., Singh, M.R., Chaudhary, A., Jain, N. and Pathak, H.(2013). Vulnerability of agriculture to climate change: district level assessment in the Indo-Gangetic plains. Indian Agricultural Research Institute, New Delhip 74.

Singh, A. and Patwardhan, A. (2012). Spatio temporal distribution of extreme weather events in India.APCBEE Procedia, 1: 258-262.

Yin, X., Guo, W. and Spiertz, J.H.(2009). A quantitative approach to characterize sink-source relationships during grain filling in contrasting wheat genotypes.Field Crops Res., 114: 119-126 